\title{
SPATIAL EFFECTS OF COVID-19 ON PERSONAL HYGIENE HABITS AMONG THE STUDENTS OF THE OYO STATE COLLEGE OF EDUCATION, LANLATE
}

\author{
Ogundele, Adeolu Tunde \\ Department of Geography, \\ Oyo State College of Education, Lanlate, Nigeria. \\ tundeogundele72@gmail.com \\ Oladipo Micheal Olukayode \\ Department of Geography \\ Oyo State College of Education, Lanlate, Nigeria. \\ larryayab@gmail.com
}

\begin{abstract}
This study attempts an evaluation of the effects that the outbreak of the corona virus disease (COVID-19) have on the personal hygiene habits among the students' of the Oyo State College of Education, Lanlate. The study used empirical survey of three hundred randomly selected students from the six schools of the college. Questionnaire, oral interview and personal observation were used as instruments of data collection. Data collected were analysed through the use of table and simple percentages. The findings showed that the awareness of the existence of COVID-19 was very high though some respondents doubt the existence of the disease. The study also revealed that there was improvement in the personal hygiene habits of the students this is depicted in constant washing of hands with soaps, improved environmental sanitation, wearing of face masks among other habits. Inadequate supply of potable water, defective campaign against the disease, high cost of hand sanitisers and face masks hinder the observation of COVID-19 protocols. It was recommended that government should improve on potable water supply to the people, materials needed to stop the spread of the virus should be subsidized or distributed free and people should improve their personal hygiene and environmental sanitation habits.
\end{abstract}

Keywords: COVID-19, Personal Hygiene, Environmental sanitation Habits, Students 


\section{Introduction}

The outbreak of the Corona virus otherwise known as COVID-19 caught the global health system unaware. Even the advanced countries of the world with formidable health facilities were unable to muster enough medical artistry to combat the rampaging disease. Hence, the World Health Organisation (WHO) labeled the outbreak of the disease as pandemic. The first COVID-19 case was diagnosed in Wuhan city in China in December of the year 2019 but today the disease has been detected in nearly all countries of the world. The index case in Nigeria was detected in Lagos on the $27^{\text {th }}$ of February, 2020. As at August 2020 there were 52,800 confirmed cases and a total of 1,007 fatalities (NCDC, 2020). The global confirmed cases remained at 24 million with close to 820,000 deaths (WHO, 2020). Similarly, in the same period the Africa Centre for Disease Control (ACDC) reported that confirmed case of COVID-19 has risen to 1,203,769 and the deaths recorded was 28,289.

As COVID -19 continued to ravage the world population so also is the cure for the disease continues to become elusive despite the struggle of medical researchers to develop an appreciable vaccine for it. In other words there is no known cure for the disease. However, it has been confirmed by experts that the disease is spreading through droplets when an infected person coughs or sneezes, through contaminated surfaces among other means of infection (Faisal, 2020). Like other viral diseases however, some precautionary measures have been identified to prevent and slow down the rate of infection of the virus. WHO (2020) said regular hand washing with soap (hand hygiene) prevents the spread of the virus. Other precautionary measures include application of alcohol based hand sanitisers, the use of surgical face masks, constant showers and brushing of teeth at least twice daily, cleaning of surfaces with disinfectant, avoidance of crowded places as well as constant fumigation of residential and public places. To a greater extent these precautionary measures can be summed up to revolve round the personal hygiene of an individual

However, studies have shown that personal hygiene and the ingredients needed to sustain it with environmental sanitation are in poor state in most countries in Africa Nigeria inclusive (Ogundele, 2015; Oladipo , 2017). Approximately 600million Africans live in urban areas out of which 6 percent of them live in slums. Many Africans urban households live in a single room and about 80percent do not have access to potable water and reside in overcrowded neighbourhood. Only 34 percent of the African population has access to hand washingfacilities. These problems coupled with weak health systems and underlying health conditions among the populace (this increases the fatality of COVID-19) appear to render the continent vulnerable to high case of the disease.

Notwithstanding these problems the quest to halt the spread of this disease depends largely on the people's ability to improve their personal hygiene and environmental sanitation habits. This studytherefor attempts an evaluation of how the incidence of COVID- 19 in the country has influenced the people's personal hygiene habits with specific reference to the students of the Oyo State College of Education, Lanlate.

\section{Objectives of the Study}

It has been established that researchers are yet to find a cure for COVID-19, therefore the major precautionary measures against the spread of the virus is personal hygiene and constant environmental sanitation. Taking into consideration that personal hygiene and environmental sanitation habits of Nigerian are poor (Ogundele, 2015; Oladipo, 2017) prior to the pandemic. The Federal government has included emergency response activities across all states to include health 
and personal hygiene campaigns directed at the members of the public (NCDC, 2020). These campaigns were organized to ensure knowledge improvement and the correction of certain misconceptions that have been widely circulated among the people. The campaigns include education on the precautionary measures such as regular hand washing with soap and water, application of alcohol based hand sanitisers, wearing of face masks, social distancing, disinfection of surfaces among others. This study therefore attempts an evaluation of the impacts of COVID 19 and the public awareness campaigns generated as a result of its outbreak on the personal hygiene of the students of Oyo State College of Education, Lanlate. Apart from this the study also examined the perception of the students about the disease, the precautionary measures embraced as well as the challenges faced in adhering to habits that can prevent COVID -19.

\section{COVID-19: Historical Background and Clinical Manifestation}

Towards the end of December 2019 precisely on 31 December, the World Health Organization (WHO) was formally notified about a cluster of cases of pneumonia in Wuhan City, home to 11 million people and the cultural and economic hub of central China (Chaplin, 2020). By 5 January, 59 cases were known and none had been fatal. As at January 15 there were 282 confirmed cases, of which four were in Japan, South Korea and Thailand. There had been six deaths in Wuhan, 51 people were severely ill and 12 were in a critical condition. (WHO, 2020). The virus responsible was isolated on 7 January and its genome shared on 12 January. The cause of the severe acute respiratory syndrome that became known as COVID-19 was a novel coronavirus, SARS-CoV-2. By August ending the world had recorded of over 24 million cases. The virus is also spreading to African countries including Algeria, South Africa, Senegal, Burkina Faso, Cameroon, Nigeria, and Côte d'Ivoire. In Nigeria, weak health system, fund, lack of materials especially for testing and the populace perception of the disease as a hoax (an exaggerated illness with intention for corruption) tremendously affected the collation of accurate data about the disease. However, the Nigeria Centre for Disease Control (NCDC) reported 52,800 confirmed cases and a total of 1,007 fatalities as at August (NCDC, 2020).

The most common symptoms of COVID-19 are fever/chills, dry or productive cough, sore throat, general weakness, pain, rhinorrhoea and diarrhoea. However, it has been noted that these symptoms may not be representative of all COVID-19 cases. Complications include cardiomyopathy, thrombosis, acute kidney injury and encephalitis.Probable risk factors for severe disease and death include increasing age, being of minority ethnic background, immunosuppression, hypertension, diabetes, cardiovascular disease, chronic respiratory disease, obesity, smoking and cancer. Men in these groups appear to be at higher risk. Chronic obstructive pulmonary disease (COPD), cardiovascular disease and hypertension are strong predictors of admission to intensive care (Jordan, 2020). The preferred way to build herd immunity is through vaccination. It is currently uncertain when a vaccine will be available to the general population. How quickly production can be scaled up to meet international demand is another unknown.

\section{Methodology}

\section{Area of Study}

The permanent site of the college is located in the Northern part of Lanlate, the Headquarters of Ibarapa North East Local Council Development Area. Oyo State College of Education, Lanlate has undergone a series of change in nomenclature in the last decade. It was formerly established as a campus of Emmanual Alayande College of Education, Oyo in the year 2001 by Alhaji Lam Adesina administration. It was granted full autonomy as a full fledge college in 2016 and 
christened The College of Education, Lanlate. However, due to the amendment made to the edict establishing the college by the Oyo State Government, the name was changed to Oyo State College of Education, Lanlate in the year 2020. The permanent site of the college is located in the Northern part of Lanlate, the Headquarters of Ibarapa North East Local Council Development Area. The college is made up of six different schools namely;
i. School of Arts and Social Sciences
ii. School of Early Childhood and Primary Education
iii. School of General Education
iv. School of Languages
v. School of Science
vi. School of Vocational and Technical Education

The total population of the students $(100 \mathrm{~L}-300 \mathrm{~L})$ as at the end of 2019/2020 session stood at 1,200 students (Academic Affairs Unit, COEL 2020).

\section{Material and Methods}

The study design was descriptive in nature. Materials are sourced from both primary and secondary sources. The primary data were collected through questionnaire, personal observation and oral interview. The questionnaire form consisted of two sections. Section one is on the Bio data of the respondents while section two was on the items of the study as spelt out in the objectives section. The study was limited to students in the six schools in the college. In each school sampled, fifty (50) students were randomly selected making a total of three hundred respondents. Personal observation of the students' hand washing habits (since hand washing devices were provided in strategic locations within the college) and oral interview were used to validate data obtained through questionnaire. The secondary data were sourced from print materials and the internet. The data collected were analyzed and interpreted using percentages andcross tabulation. Information derived was reported in the results and discussion.

\section{Results and Discussion}

\section{Socio Demographic Characteristics of the Students}

Table 1: Socio- demographic data of the students

\begin{tabular}{|c|l|l|}
\hline Bio- data & Frequency & \% \\
\hline \multicolumn{3}{|c|}{ Age group (Yrs) } \\
\hline$>20$ & 100 & 33.33 \\
\hline $20-25$ & 160 & 53.33 \\
\hline $25-30$ & 35 & 11.67 \\
\hline 30 & 05 & 01.67 \\
\hline Total & $\mathbf{3 0 0}$ & $\mathbf{1 0 0}$ \\
\hline \multicolumn{2}{|c|}{ Sex } & 126 \\
\hline Male & 174 & 42 \\
\hline Female & $\mathbf{3 0 0}$ & 58 \\
\hline Total & 80 & $\mathbf{1 0 0}$ \\
\hline \multicolumn{2}{|c|}{ Level of Study } \\
\hline Year one & 120 & 26.67 \\
\hline Year two & 100 & 40 \\
\hline Year three & $\mathbf{3 0 0}$ & 33.33 \\
\hline Total & 100 \\
\hline
\end{tabular}

Source: Field Survey, 2020 
Of the total number of respondents sampled, majority are within the age bracket 20- 25 years i.e $160(53.33 \%)$, this is followed by respondents from 20years and below which are $100(33.33 \%)$, others which are between 25- 30 years are 35 (11.67\%), while respondents which are over 30 years are $5(1.67 \%)$.

\section{Level of Awareness of COVID-19 among the Students}

\section{Table 2: Level of awareness}

\begin{tabular}{|l|l|l|l|}
\hline S/N & \multicolumn{1}{|c|}{ Variable } & Frequency & \% \\
\hline i. & COVID-19 is a very contagious disease & 205 & 68.33 \\
\hline ii. & It's not as serious as the campaign against it. & 50 & 16.67 \\
\hline iii. & It does not exist & 45 & 15 \\
\hline & Total & $\mathbf{3 0 0}$ & $\mathbf{1 0 0}$ \\
\hline
\end{tabular}

\section{Source: Field Survey, 2020}

Table 2 revealed that there was strong awareness about the outbreak of COVID-19 among the students, for instance, $205(68.33 \%)$ agreed that the disease was a very contagious one with high rate of fatality. However, $50(16.67 \%)$ were of the opinion that the disease was not as serious as the government want them to believe it. Similarly, 45 (15\%) did not believe in the existence of the disease and that everything about the disease was a hoax. Previous study had also revealed that people had mixed perception about the disease while some believed in the existence of COVID-19 some believed that the disease was political and a mean of diverting government fund (Ilesanmi and Afolabi, 2020).

\section{Personal Hygiene Habits against COVID-19}

\section{Table3: Precautionary Measures}

\begin{tabular}{|l|l|l|l|}
\hline S/N & Personal Hygiene Habits & Frequency & $\mathbf{\%}$ \\
\hline i. & Constant washing of hands & 250 & 15.27 \\
\hline ii. & Wearing of face masks & 190 & 11.61 \\
\hline iii. & Application of alcohol based hand sanitisers & 102 & 6.23 \\
\hline iv. & Cleaning of teeth & 300 & 18.33 \\
\hline v. & Constant showers & 300 & 18.33 \\
\hline vi. & Consumption of warm food & 156 & 9.53 \\
\hline vii. & Proper sanitation & 185 & 11.30 \\
\hline viii. & Social distancing & 154 & 9.40 \\
\hline & Total & 1637 & 100 \\
\hline
\end{tabular}

Source: Field Survey, 2020

(Multiple Responses)

Series of personal hygiene habits were employed by the respondents to avoid contracting COVID19 as shown in Table 3. In the order of popularity cleaning of teeth and taking regular shower /bath are more popular. All the respondents agreed to imbibe the habits; this is probably because these habits are fundamental to the principles of personal hygiene. Constant washing of hands $(15.27 \%)$ and wearing of face masks (11.61\%), proper environmental sanitation (11.30\%), consumption of warm food $(9.53 \%)$, social distancing $(9.40 \%)$. The least practiced habit is the application of alcohol- based hand sanitizers. Though, most of these habits were observed by the people before the outbreak of the disease, researches revealed thatthe only remedy against contracting the virus is improving one's personal hygiene. As a result,to a greater extent this has compelled most people to improve on their personal hygiene habits (especially constant hand 
washing with soap, wearing of face masks, application of hand sanitisers) as well as observing environmental sanitation. However, observation revealed that the adherence to the wearing of face masks and social distancing was low, so also was the methods adopted in wearing of the masks; some respondents did not wear their masks as required while most masks were made from materials that cannot prevent the virus from infecting the host.

\section{Challenges to People's Adherence to Habits that Prevent COVID-19}

\begin{tabular}{|l|l|l|l|}
\hline S/N & Challenges & Frequency & $\mathbf{\%}$ \\
\hline i. & Inadequate potable water & 200 & 22.22 \\
\hline ii. & Expensive materials (face masks and hand sanitizers) & 250 & 27.78 \\
\hline iii. & Economic Factors & 264 & 29.33 \\
\hline iv. & Inadequate campaign/education on COVID-19 & 186 & 20.67 \\
\hline & Total & $\mathbf{9 0 0}$ & $\mathbf{1 0 0}$ \\
\hline
\end{tabular}

\section{Source: Field Survey, 2020 (Multiple Response)}

In as much as the people are ready to observe COVID-19 protocol, a number of challenges have been observed by the respondents as hindrance; the major factor identified was economic factor (29.33\%). This is followed by expensive prices of face masks and alcohol based hand sanitisers $(27.78 \%)$, inadequate potable water $(22.22 \%)$ as well as inadequate campaign on the need to embrace COVID- 19 protocols. Most Nigerians are low income earners whose means of livelihood require interacting with people especially those who hawk their goods at markets and motor parks, with no other means of economic survival. This set of people found it difficult to observe COVID-19 protocols. Furthermore, it was observed that as a result of the COVID-19 outbreak cost of purchasing materials such as face masks and alcohol based hand sanitizers skyrocketed beyond the reach of common people. Hence, people resulted to wearing all sort of masks which cannot prevent the spread of the virus. Many even go about without putting them on.Although, the governments at all levels have set machineries in motion to educate the populace on the COVID-19 protocols, the campaign methods adopted are channeled through mass media which are beyond the reach of most targeted audience.

\section{Recommendations}

Based on the findings of this study the following recommendations were put forward for stakeholders; there is need to complement the campaign against COVID-19 through mass media with other methods such as community engagements, house to house campaign among others. However, the campaigners must be people who have been trained for such programmes.

There is need for government to subsidise medical materials prescribed for the prevention of the spread of the virus such as face masks, alcohol-based hand sanitisers among other materials. In addition government should monitor the distribution of the materials provided by her agents so as to get to the target population.

There is need to provide palliatives for the people so as to cushion the effect of economic hardship caused by the outbreak of the virus and its attendant lockdown of economic activities. There is need for people to show a positive attitude towards personal hygiene and environmental sanitation. This will go a long way in prevention of COVID- 19 and promotion of their general well-being. 
Infrastructural facilities especially provision of potable water should be given serious attention because they greatly influence personal hygiene and environmental sanitation habit of the people.

\section{Conclusion}

There is no doubt that COVID-19 has come to stay as one of the diseases ravaging mankind. This reality and the fact that no specific cure has been found for the disease requires for positive attitudinal change from the people. Personal hygiene and environmental sanitation which have been at the lowest ebb from time immemorial among Nigerians need to be improved upon. This, no doubt would stem the tide of the spread of COVID-19. 


\section{References}

ACDC, (2020).Coronavirus disease 2019 (COVID-19): Africa centre for disease control. Available at https://africacdc.org/\%20covid-19/

Chaplin, S. (2020). COVID-19: A brief history and treatments in development. Wiley Clinical Healthcare Hub, Prescriber ( 31) 5: p. 23-28. Available at https://doi.org/10.1002/psb.1843

Faisal, M. (2020).Association Between Good Personal Hygiene and Covid-19 Pandemic:

A PreventiveMeasure.International Journal of Health and Life Science.doi: 10.5812/ijhls. 104268 .

Ilesanmi, O. \&Afolabi, A. (2020).Perception and practices during the COVID-19 pandemic in an urban community in Nigeria: A cross-sectional study.PeerJ 8:e10038 DOI 10.7717/peerj.10038.

Jordan, R. E. (2020). Covid-19: Risk factors for severe disease and death. BMJ 2020; 368: m1198.

NCDC. (2020).COVID-19 outbreak in Nigeria situation report-Abuja: Nigeria centre for disease Availableathttps;//ncdc.gov.ng/themes/common/files/sitreps/0daa083aeed110eddba8937c1f9 0a6d9.pdf

Ogundele, A. T. (2015).An appraisal of environmental sanitation practices in Ibarapa East Local Government Area of Oyo state. Nigerian Journal of Languages, Arts, Education and Social Sciences, 6 (2):51-68

Oladipo, M.O. (2020). Waste Disposal Habits of Students of College of Education Lanlate, Oyo State. Journal of Arts and Social Sciences Update, 6(1): 40-45

UNO (2020). Policy brief: Impact of COVID-19 in Africa

WHO. (2020).Coronavirus disease 2019 (COVID-19) situation report-51 Geneva: World Health Organization.Available athttps://covid19.who.int/. 